\title{
EFEKTIVITAS BIBLIOKONSELING UNTUK MENINGKATKAN EMPATI REMAJA DI RUMAH PINTAR “BUNGA PADI" KECAMATAN BALEREJO, KABUPATEN MADIUN
}

\author{
Dahlia Novarianing Asri* \\ Tyas Martika Anggriana*
}

\begin{abstract}
Abstrak
Penelitian ini bertujuan untuk mengetahui efektifitas bibliokonseling untuk meningkatkan empati remaja di Rumah Pintar "Bunga Padi" Kecamatan Balerejo, Kabupaten Madiun. Penelitian ini menggunakan metode eksperimen semu (quasi experiment). Desain penelitian yang digunakan adalah rancangan pre-test dan posttest.

Subjek penelitian ini adalah remaja di Rumah Pintar "Bunga Padi" di Kecamatan Balerejo, Kabupaten Madiun. Subjek penelitian dipilih secara purposive. dari 28 remaja di Rumah Pintar "Bunga Padi" Kecamatan Balerejo, Kabupaten Madiun diperoleh 8 orang remaja yang dijadikan sebagai subjek penelitian dengan rincian terdapat $75 \%$ (6 orang) remaja yang memiliki tingkat empati rendah dan $25 \%$ (2 orang) remaja memiliki tingkat empati sangat rendah. Data yang terkumpul kemudian dianalisis dengan analisis statistik non-parametrik, yaitu dengan uji wilcoxon.

Berdasarkan uji hipotesis diperoleh hasil bahwa hipotesis diterima, artinya teknik bibliokonseling efektif untuk meningkatkan empati remaja di Rumah Pintar "Bunga Padi” Kecamatan Balerejo, Kabupaten Madiun. Skor subjek pada saat pretest dan posttest menunjukkan perbedaan. Skor pretest subjek masuk dalam kategori sangat rendah dan rendah, setelah diberikan treatment bibliokonseling skor subjek masuk dalam kategori tinggi dan sangat tinggi
\end{abstract}

Kata Kunci: Bibliokonseling, Empati

* Dahlia Novarianing Asri dan Tyas Martika Anggriana adalah Dosen Program Studi Bimbingan dan Konseling Fakultas Ilmu Pendidikan IKIP PGRI Madiun 


\section{Pendahuluan}

Empati dapat diartikan

kesanggupan untuk turut merasakan

apa yang dirasakan orang lain dan

kesanggupan untuk menempatkan diri

dalam keadaan orang lain. Empati

membuat kita dapat turut merasa

senang dengan kesenangan orang lain,

turut merasa sakit dengan penderitaan

orang lain, dan turut berduka dengan

kedukaan orang lain. Rasa empati

perlu dikembangkan pada masa

sekarang, karena dalam lingkungan

masyarakat telah mulai terjadi

pergeseran nilai menjadi masyarakat

yang egois individualistis. Kodrat

manusia sebagai makhluk sosial perlu

dikembangkan lagi, karena pada

dasarnya manusia tidak akan mampu

hidup sendiri tanpa bantuan orang lain.

Empati di butuhkan oleh setiap

individu dalam berinteraksi dengan orang-orang di lingkungan sekitarnya.

Empati ini akan membuat individu terbiasa melihat sesuatu dari sisi individu lain. Empati akan membuat individu bisa memisahkan orang dan masalahnya, empati akan mendorong individu untuk lebih melihat bagaimana menyelesaikan masalah daripada bagaimana menyerang orang lain. Empati menjadi suatu yang harus dimiliki oleh setiap individu karena dengan berempati, menunjukkan bahwa individu adalah manusia yang berperasaan, dan akhirnya menuntun individu menjadi manusia yang bermanfaat untuk sesama.

Batson \& Coke (dalam Brigham, 1991) mendefinisikan empati sebagai suatu keadaan emosional yang dimiliki seseorang yang sesuai dengan apa yang dirasakan oleh orang lain. Eisenberg 
dan Faber (dalam Baron dan Byne, 1994) mendefinisikan empati sebagai respon individu terhadap keadaan emosional orang lain, seolah individu yang bersangkutan mengalami sendiri keadaan emosi serupa yang dialami orang tersebut, misalnya seorang individu ikut merasa sedih melihat kesedihan orang lain. Ahli lain, Brammer dan MacDonald (1996) menekankan bahwa dengan empati, seseorang mencoba dengan usaha aktif untuk menempatkan diri pada internal frame of reference orang lain tanpa kehilangan obyektivitasnya.

Menurut pendapat ahli, respon empati dibagi menjadi dua komponen, yaitu a) komponen kognitif, yaitu proses-proses intelektual untuk memahami perspektif orang lain secara tepat, dan b) komponen afektif, yaitu kecenderungan seseorang untuk mengalami perasaan-perasaan emosional orang lain. Lebih lanjut, Davis (dalam Latifah, 2002) membuat skala empati dengan menjabarkan kedua komponen empati di atas ke dalam empat aspek yaitu 1) aspek perspective taking, yaitu kecenderungan seseorang untuk mengambil sudut pandang psikologis orang lain secara spontan; 2) aspek fantasy, yaitu kemampuan seseorang untuk mengubah diri mereka secara imajinatif dalam mengalami perasaan dan tindakan dan karakter khayal dalam buku, film atau sandiwara yang dibaca atau ditonton, 3) aspek emphatic concern, yaitu perasaan simpatik yang berorientasi pada orang lain dan perhatian terhadap kemalangan orang lain, dan 4) aspek personal distress, yaitu 
kecemasan pribadi yang berorientasi

pada diri sendiri serta kegelisahan

dalam menghadapi setting

interpersonal yang tidak

menyenangkan.

Tidak semua individu mudah berempati dengan orang lain. Reaksi empati terhadap orang lain berbeda antara individu satu dengan individu lain yang dipengaruhi oleh pengalaman masa lalunya. Individu yang memiliki rasa empati yang tinggi ditunjukkan dengan kebiasaan melukiskan dirinya sebagai orang yang lebih toleran, mampu mengendalikan diri, ramah, mempunyai pengaruh serta bersifat humanistik. Menurut Hogan (dalam Latifah, 2002) lima karakteristik orang yang disebut mempunyai rasa empati yang tinggi yaitu: (1) kemampuan dalam berperan imajinatif bersandiwara dan humor;
(2) sadar akan pengaruh seseorang terhadap orang lain; (3) kemampuan mengevaluasi motif-motif orang lain; (4) pengetahuan tentang motif-motif dan perilaku orang lain; (5)mempunyai rasa pengertian social. Menumbuhkan rasa empati harus dimulai sejak kecil, mulai dari dalam keluarga, sekolah, dan lingkungan. Lingkungan yang penuh perhatian, kasih sayang dan rasa aman adalah prasyarat penting bagi tumbuhnya empati pada anak. Apabila sejak kecil anak-anak sudah terbiasa untuk "mendengar, melihat, dan merasakan" dengan perspektif orang lain, maka akan tumbuh menjadi individu yang bisa memahami orang lain sebagaimana dirinya memahami dirinya sendiri.

Sesuai dengan tahap perkembangan moral individu, remaja 
yang berada pada rentang usia 13-16

tahun memasuki masa caring, yaitu saatnya mengembangkan sifat ramah,

peduli kepada orang lain, memaafkan dan membantu orang lain yang kesulitan. Sifat dan perilaku moral tersebut tidak dengan mudah dapat tumbuh dalam diri siswa, namun perlu dilakukan proses penanaman, penumbuhan, pengembangan dan akhirnya menjadi perilaku yang menetap yang melekat dalam diri siswa.

Langkah nyata yang dapat

dilakukan untuk menumbuhkan rasa

empati siswa adalah melalui pelayanan

Bimbingan dan Konseling. Salah satu alternatif teknik Bimbingan dan Konseling yang dapat digunakan adalah teknik bibliokonseling. Melalui teknik bibliokonseling yang berjalan secara sistematis, terencana dan mudah digunakan dapat membantu siswa menganalisis nilai moral dan menstimulasi pemikiran kritis, mengembangkan kesadaran diri, meningkatkan konsep diri, dan memperbaiki penilaian pribadi dan sosial (Dhani M. Handarini, 2011).

Bibliokonseling merupakan suatu teknik pendekatan konseling yang diadaptasi dari teknik biblioterapi. Jachna (dalam Yossy Suparyo, 2011) mengemukakan bahwa biblioterapi adalah dukungan psikoterapi melalui bahan bacaan untuk membantu seseorang yang mengalami permasalahan personal. Metode biblioterapi dapat digunakan untuk membantu klien yang mengalami kesulitan untuk mengungkapkan permasalahannya secara verbal.

Jika diterapkan dalam Bimbingan dan Konseling, bibliokonseling dapat 
dikatakan sebagai pendekatan

Bimbingan dan Konseling dengan menggunakan informasi atau pengetahuan yang terdapat dalam buku pustaka, misalnya dari komik, buku cerita, artikel dari koran atau majalah, novel, maupun tulisan ilmiah. Buku pustaka yang ditunjuk harus sesuai dengan masalah siswa. Setelah membaca buku tersebut, diharapkan siswa terbantu menyelesaikan masalah yang dihadapi. Selain itu, buku yang digunakan harus sesuai dengan usia perkembangan siswa, sehingga bahasa dalam buku tersebut dapat dipahami dengan mudah.

Dengan menggunakan buku sebagai media untuk membantu siswa, guru dapat menghindari kemungkinan munculnya kesenjangan yang terjadi. Dari buku yang diberikan oleh konselor, siswa terbantu mendapatkan informasi lengkap tanpa harus merasa malu. Kelebihan lain bibliokonseling adalah siswa merasa lebih aman. Pemanfaatan buku bacaan untuk mencari alternatif solusi atas masalah yang dihadapi, membuat siswa tidak khawatir masalahnya diketahui oleh orang lain.

Oslen (dalam Yossy Suparyo, 2011) menyarankan lima tahap penerapan Bibliokonseling, yaitu :

1. Motivasi, konselor dapat memberikan kegiatan pendahuluan seperti permainan yang dapat memotivasi peserta untuk terlibat secara aktif dalam kegiatan konseling

2. Berikan waktu yang cukup. Konselor mengajak peserta untuk membaca bahan bacaan yang telah disiapkan hingga selesai.

3. Lakukan inkubasi. Konselor 
memberikan waktu pada peserta

untuk merenungkan materi yang baru saja dibaca.

4. Tindak lanjut. Tindak lanjut dilakukan dengan metode diskusi.

Lewat diskusi, peserta mendapatkan ruang untuk saling tukar pandangan sehingga memunculkan gagasan baru. Selanjutnya, konselor membantu peserta untuk merealisasikan pengetahuan itu dalam hidupnya.

5. Evaluasi. Sebaiknya evaluasi dilakukan secara mandiri oleh peserta. Hal ini memancing peserta untuk memperoleh kesimpulan yang tuntas dan memahami arti pengalaman yang dialami

Berdasarkan uraian diatas, muncul pertanyaan penelitian seberapa efektif teknik bibliokonseling dapat digunakan untuk mengembangkan empati remaja? Penelitian ini difokuskan untuk mengukur efektifitas bibliokonseling untuk mengembangkan empati remaja.

Empati adalah kemampuan individu dalam menempatkan diri pada pikiran dan perasaan orang lain sehingga mampu merasakan keadaan emosi orang tersebut. Bibliokonseling adalah pendekatan dalam Bimbingan dan Konseling dengan menggunakan informasi atau pengetahuan yang terdapat dalam buku pustaka, misalnya dari komik, buku cerita, artikel dari koran atau majalah, novel, maupun tulisan ilmiah.

\section{Metode Penelitian}

Penelitian ini menggunakan metode eksperimen semu (quasi experiment). Desain penelitian yang 
digunakan adalah rancangan pre-test

dan post-test. Penelitian ini menggunakan satu variable terikat yaitu empati. Subjek penelitian ini adalah remaja di Rumah Pintar "Bunga Padi” di Kecamatan Balerejo, Kabupaten Madiun. Subjek penelitian dipilih secara purposive, yaitu dengan cara mengukur tingkat empati siswa dengan menggunakan skala empati.

Prosedur intervensi dilakukan melalui langkah-langkah sebagai berikut: (1) Memberikan bacaan bertema empati; (2) Melakukan refleksi isi bacaan dan refleksi diri; (3) Uji coba komitmen; (4) Refleksi pengalaman; (5) Pengembangan komitmen.

Pemberian intervensi berupa bacaan dilakukan 8 kali untuk melihat secara jelas hasil pengukuran pre-test dan post-test. Setelah dilakukan pengukuran dan diketahui nilai pre-test dan post-testnya, langkah selanjutnya adalah membandingkan antar skor apakah ada kenaikan skor atau tidak.

Instrumen penelitian yang digunakan untuk mengukur empati berupa skala pengukuran yang disusun berdasarkan aspek yang dikemukakan oleh Davis (dalam Latifah, 2002): (1) perspective taking; (2) fantasy; (3) emphatic concern, (4) personal distress.

Data yang terkumpul kemudian dianalisis dengan analisis statistik nonparametrik, yaitu dengan uji wilcoxon.

\section{Hasil Penelitian}

Berdasarkan data pretest empati siswa, dari 28 remaja di Rumah Pintar "Bunga Padi" Kecamatan Balerejo, Kabupaten Madiun diperoleh 8 orang remaja yang dijadikan sebagai 
subjek penelitian dengan rincian terdapat $75 \%$ (6 orang) remaja yang memiliki tingkat empati rendah dan 25 $\%$ (2 orang) remaja memiliki tingkat empati sangat rendah.

Pengumpulan data posttest dilakukan di akhir pertemuan untuk mengetahui tingkat keberhasilan treatment dan mengetahui perubahan tingkat empati remaja. Penelitian ini hanya menggunakan kelompok eksperimen dan tidak menggunakan kelompok kontrol.

Perbandingan skor kelompok eksperimen pada pretest dan posttest dijabarkan dalam tabel berikut ini:

Tabel 4. Data Skor Pretest dan Posttest Empati Siswa

\begin{tabular}{|c|c|c|c|c|c|}
\hline $\begin{array}{r}\text { Inisial } \\
\text { Subjek }\end{array}$ & $\begin{array}{c}\text { Skor } \\
\text { Pretest }\end{array}$ & Kategori & $\begin{array}{c}\text { Skor } \\
\text { Posttest }\end{array}$ & Kategori & $\begin{array}{l}\text { Perbedaan } \\
\text { Skor }\end{array}$ \\
\hline Subjek 1 & 40 & $\begin{array}{l}\text { Sangat } \\
\text { Rendah }\end{array}$ & 80 & Tinggi & 40 \\
\hline Subjek 2 & 64 & Rendah & 100 & Tinggi & 36 \\
\hline Subjek 3 & 65 & Rendah & 109 & $\begin{array}{l}\text { Sangat } \\
\text { Tinggi }\end{array}$ & 44 \\
\hline Subjek 4 & 67 & Rendah & 106 & $\begin{array}{l}\text { Sangat } \\
\text { Tinggi }\end{array}$ & 39 \\
\hline Subjek 5 & 36 & $\begin{array}{l}\text { Sangat } \\
\text { Rendah }\end{array}$ & 78 & Tinggi & 42 \\
\hline Subjek 6 & 70 & Rendah & 110 & $\begin{array}{l}\text { Sangat } \\
\text { Tinggi }\end{array}$ & 40 \\
\hline Subjek 7 & 68 & Rendah & 108 & $\begin{array}{l}\text { Sangat } \\
\text { Tinggi }\end{array}$ & 40 \\
\hline Subjek 8 & 72 & Rendah & 108 & $\begin{array}{l}\text { Sangat } \\
\text { Tinggi }\end{array}$ & 36 \\
\hline
\end{tabular}

Berdasarkan tabel diatas dapat pretest dan posttest menunjukkan dilihat bahwa skor tiap subjek perbedaan. Skor pretest subjek masuk bervariasi. Skor subjek pada saat dalam kategori sangat rendah dan 
rendah, setelah diberikan treatment bibliokonseling skor subjek masuk dalam kategori tinggi dan sangat tinggi.

Pengujian hipotesis dilakukan
dengan menggunakan uji wilcoxon

untuk mengetahui ada atau tidaknya

perbedaan tingkat empati remaja

sebelum dan sesudah diberikan

treatmen bibliokonseling. Hipotesis

penelitian ini adalah teknik

bibliokonseling efektif untuk

meningkatkan empati remaja. Uji

hipotesis dilakukan dengan

menggunakan bantuan program SPSS

for windows 16.0.

Berdasarkan hasil uji hipotesis pada kolom Asymp. Sig. (2-tailed) atau asymtotic significance untuk uji dua sisi adalah 0,017 (nilai Sig. $<\alpha=$ $0,05)$, berarti bahwa hipotesis diterima, artinya teknik bibliokonseling efektif untuk meningkatkan empati remaja di Rumah Pintar "Bunga Padi" Kecamatan Balerejo, Kabupaten Madiun.

$\begin{array}{rrr}\text { Empati merupakan sikap } \\ \text { mampu } & \text { menempatkan diri }\end{array}$
sebagaimana kondisi yang sedang dialami oleh orang lain. Masa remaja adalah periode perkembangan moral masa caring yaitu saatnya mengembangkan sifat ramah, peduli kepada orang lain, memaafkan dan membantu orang lain yang kesulitan. Pada kondisi awal terlihat bahwa subjek memiliki tingkat empati rendah dan bahkan sangat rendah. Hal ini berarti bahwa subjek kurang memiliki kemampuan untuk turut merasakan apa yang dirasakan oleh orang lain serta belum dapat menempatkan diri dalam keadaan orang lain. 
Teknik bibliokonseling yang telah dilakukan efektif digunakan untuk meningkatkan empati remaja. Hal ini terjadi karena didalam pelaksanaan bibliokonseling subjek memiliki kesempatan untuk membaca bahan bacaan yang telah disediakan, memahami isi bacaan, mendiskusikan dan merefleksikan isi bacaan. Bahan bacaan yang dipilih berisikan pesan moral tentang pentingnya empati. Dengan demikian, subjek dapat belajar tentang empati dari alur cerita, sikap tokoh dalam bacaan, mendalami karakter tokoh dan mengidentifikasikannya ke dalam kehidupan pribadinya. Pada akhir treatmen terlihat bahwa subjek menunjukkan peningkatan empati, artinya subjek sudah memiliki kemampuan untuk turut merasakan apa yang dirasakan oleh orang lain serta dapat menempatkan diri dalam keadaan orang lain.

Hasil penelitian ini dapat disimpulkan bahwa Bibliokonseling efektif untuk meningkatkan empati remaja di Rumah Pintar "Bunga Padi" Kecamatan Balerejo, Kabupaten Madiun.

Berdasarkan simpulan di atas, dapat diberikan saran sebagai berikut:

1. Manfaat Teoretis

Untuk penelitian selanjutnya, diharapkan melakukan penelitian serupa dengan menggunakan teknik lain, misalnya Videokonseling, Cinema-konseling.

2. Manfaat Praktis

Hasil penelitian ini diharapkan dapat memberikan saran bagi:

a) Subjek Penelitian Hendaknya remaja dapat memanfaatkan kegiatan 


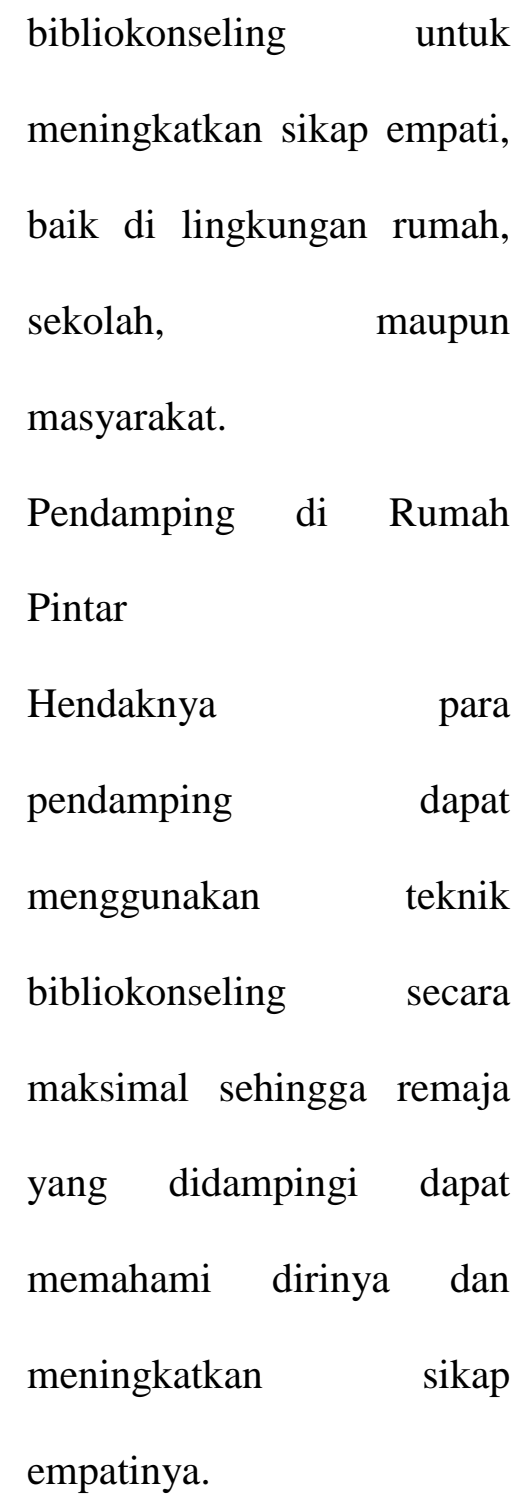

\section{Daftar Pustaka}

Baron, R. A and Byne, D. 1994. Social Psychology $\left(9^{\mathrm{t}_{1}}\right)$. Singapore: Allyn Bacon.

Brammer, L. M and MacDonald, G. 1996. The Helping Relationships Process and Skills ( $6^{\mathrm{h}}$ ed) Boston: Allyn \& Bacon.

Brigham, J.C. 1991. Social Psychology. Second Edition. New York : HarperCollins Publisher Inc.

Dhani M. Handarani. 2011. Teknik dan Strategi Bimbingan dan Konseling untuk Pendidikan Karakter. Materi Seminar dan Lokakarya Nasional, $15-18$ Juni 2011. Universitas Negeri Malang

Latifah Tri Wardhati. 2002. Pemaafan ditinjau dari empati dan penilaian terhadap peristiwa yang menyakitkan dalam hubungan interpersonal yang erat. Tesis. Yogyakarta: Fakultas Psikologi Universitas Gadjah Mada.

Yossy Suparyo. 2011. Biblioterapi, kekuatan penyembuhan lewat pengetahuan.

Web.kombinasi.net/Biblioterapikekuatan-penyembuhan-lewatpengetahuan.pdf.

Diakses tanggal 3 Oktober 2011. 